\title{
Influence of Fuel System Variations on Performance and Emission Characteristics of Combined Air-Wall Guided Mode Modified GDI engine with Alcoholic Fuels and Exhaust Gas Recirculation
}

\section{Shivakumar Nagareddy}

Bannari Amman Institute of Technology Department of Mechanical Engineering

Kumaresan Govindasamy ( $\nabla$ kumareshgct@gmail.com )

Bannari Amman Institute of Technology Department of Mechanical Engineering https://orcid.org/0000-0001-9084-9101

\section{Research Article}

Keywords: Blended Fuels, GDI Engine, Air-Wall Guided Mode, Alcohol Blends, Modified GDI Engine, Gasoline Blends

Posted Date: January 3rd, 2022

DOI: https://doi.org/10.21203/rs.3.rs-1121676/v1

License: (c) (i) This work is licensed under a Creative Commons Attribution 4.0 International License.

Read Full License 


\section{Abstract}

GDI engines commercially existed with spray guided mode where the fuel injector placed almost vertically and sprayed fuel is occupied throughout the volume of combustion chamber. With the advanced emission norms, NOx and Soot emissions control is the major task along with lower fuel consumption. To achieve the advanced emission norms, further modifications are required before or during combustion. Combined air-wall guided mode combustion chamber modification is the advanced stage required for further improvement in mixing and superior combustion. Air-wall combined mode involved piston crown shape modification so that the modified shape should impart turbulence effects and divert the fuel/mixture flow towards the spark plug tip to initiate the combustion process. In this study, the combined air-wall guided mode gasoline direct injection engine was tested with gasoline blends using Ethanol, Methanol and N-Butanol at 20, 35 and 50\% proportions under specific fixed conditions: $1500 \mathrm{rpm}$ speed, $10 \%$ EGR and FIP of 150 bars with three split injections at $320^{\circ}, 220^{\circ}$ and $100^{\circ}$ before TDC. Tests were conducted over these gasoline blend proportions for engine performance and emission characteristics and achieved beneficial results with E20 gasoline blend over the entire applied torque values.

\section{Introduction}

In gasoline engines, there were many development stages happened in fuel supply system and currently gasoline direct fuel injection is the latest technology is there with the gasoline engines where the gasoline is directly injected into an engine cylinder at higher pressure. To achieve the advanced emission norms, the spray guided mode strategy replaced by the combined air-wall guided mode with pent roof piston crown imparts turbulence effect for better mixing of compressed air with sprayed fuel at high pressure. Also the pent roof piston crown with small bowl which diverts the fuel sprays flow towards the spark plug to initiate the combustion. The FIP, FI timing, split injection with durations, ignition timing were also play important role over the combustion and emission characteristics of an engine.

The gasoline blends with iso-propanol and iso-Butanol from 0 to $30 \%$ by volume were tested at 20 and 40 bar injection pressures, the results show that at low temperature, the blends provide low carbon intensity because of its knocking suppress characteristics and the properties were matching with gasoline fuel (Scott et al. 2021). The emission factors of 5 vehicles tested on chassis dynamometer shows that decrease rematkably with emission standard from 11.7 to $6 \mu \mathrm{g}$ per $\mathrm{km}$ (Zheng et al. 2018).

To anticipate ignition of linear and iso-methyl or butyl alcohols with gasoline blends for enriching spark ignition, the enhanced thermo-chemistry kinetics model was developed to boost up an engine combustion performance at low temperature (Saggese et al. 2021).

$\mathrm{N}$-butanol has higher calorific value than other alcoholic fuel used; its blend result shows comparatively higher indicated mean effective pressure and thermal efficiency (Gorbatenko et al. 2019). 2, 5 Di-methyl furan has relatively higher octane number than gasoline fuel; other than ethanol, DMF's energy density 
similar to gasoline fuel. Because of higher calorific value and density, DMF blend test results show more concentration of NOx and soot particle emissions in an engine exhaust (Xu and Wang 2016; Hoang et al. 2021).

Ethanol gasoline blends were tested on a two wheeler engine at speed ranges 200, 400, 600, 800 and $1000 \mathrm{rpm}$; results show that E10 blend at $800 \mathrm{rpm}$, SFC was comparatively low, $26 \%$ gain in brake thermal efficiency at 1000 rpm, less soot particle emissions; E50 blend shows less NOx emissions; E30 blend shows comparatively low CO emissions (Sameeth et al. 2019). EGR fitted GDI engine was tested with hydrogen fuel from exhaust gas fuel reforming with side mounted solenoid fuel injector; results indicated that decrease in PN level and soot mass emissions (Fennell et al. 2014). Ethanol proportions at 10, 20 and $30 \%$ by volume with gasoline was tested and observed that $\mathrm{CO}$ and NOx emissions were reduced than gasoline and a remarkable reduction in HC emission than oxygen free gasoline (lodice et al. 2017). An increase in anhydrous ethanol-gasoline blend results in significant drop of $\mathrm{CO}$ and THC emission concentrations (Ribeiro et al. 2018). Evaluated the urban environmental impact of gasoline-ethanol blended fuels in a passenger vehicle engine with different speeds (Duarte et al. 2021).

$\mathrm{N}-H e p t a n e$ and Iso-octane gasoline binary blends at different octane numbers were tested; the ignition timings and laminar flame speeds were perfectly projected over a range of engine operating conditions (Lapointe et al. 2019). 12 and 20\% N-Butanol gasoline blends were tested for performance and emissions of SI engine and observed that $\mathrm{HC}$ and $\mathrm{CO}$ emissions were relatively lower than petrol; BSFC is found to be higher than gasoline due to its lower calorific value (Abdulazeez et al. 2018).

Methanol-gasoline blends with 5, 10 and 15\% proportions were tested repeatedly and noted that M10 blend has less BSFC compared with other blend proportions. M15 shown comparatively lower emissions than other blend fuels and also it has higher A/F ratio (Danaiah et al. 2012). Even through DMF has an option to serve as a SI engine fuel blend without any modifications, it fail to satisfy the existing emission norms, majorly NOx and soot particle emissions (Shukla et al. 2014).

Methanol-gasoline blends were burned in a small volume with the same ignition timing and the heat released in shorter time; higher pressure of exhaust gas was developed closer to TDC; increased proportions of methanol results in increased brake thermal efficiency. M85 blended fuel results in reduced of $\mathrm{HC}, \mathrm{CO}$ and PM emissions (Yanju et al. 2008).

$\mathrm{N}$-heptane methanol blended fuels were tested towards the burning characteristics and observed that the azeotropism between methanol and heptane lowers the burning quality compared to gasoline fuel (Zihe et al. 2021). Use of blended fuels with chambered type non perforated muffler to bring drowns the concentrations of $\mathrm{CO}_{2}$ emissions; the results show that $\mathrm{CO}_{2}$ emissions is at maximum level where BMEP is 3.57 bar with turbo type muffler (Chandra et al. 2020).

Economic and emissions technological advantages by using bio-fuels has imparting few public policy requirements and provides recommendations for the transition of fuel to bio-fuels based with economy (Ahmad and Tabrez 2018). 
For implementing the advanced injection parameters with effective reduced emissions and superior combustion performance. Kirloskar make, single cylinder, diesel engine gives more benefit on operating cost. SCO is the cost benefit fuel with high levels of harmful emissions and can be improved with dual fuel mode of gaseous fuels (Karthic et al. 2020). The use of methyl-ester rapeseed oil biodiesel was recommended to reduce the total mass of particulate and metal emissions from diesel engines (Coufalík et al. 2019).

The chambered turbo type muffler with methanol gasoline fuel blends was tested towards better fuel property, performance and emission characteristics (Prakash et al. 2018). On road tests were conducted to characterize the harmful gas emissions from petrol and diesel engines, the concentrations of $\mathrm{CO}$ and NOx decreased comparatively. With lower rate of EGR with modification on the intake manifold for using the engine with bio-diesel blends which results in high NOx emissions (Lanyi et al. 2020; Khan 2020).

Synthetic oil was mixed up with ethanol gasoline blends and tested for its effects towards its lubrication properties and observed that it decreases the viscosity of the engine oil an increases the acidic rating compared to gasoline fuel; also degradation of oil. E10 blend has very less impact on frictional wear properties than other blends (Khuong et al. 2017).

Gasoline, N-Butanol blends show decrement in SFC and $\mathrm{CO}_{2}$ emissions at steady state; with increase of $\mathrm{N}$-Butanol proportions in the blend results in reduced $\mathrm{HC}, \mathrm{CO}, \mathrm{NO}$ and soot emissions. Ethanol gasoline fuel blends shows significant reduction of $\mathrm{HC}, \mathrm{PN}$ and NOx than other alcohol blends (Haifeng et al. 2019).

Methanol gasoline blends at 5, 10, 20,30 and 50\% proportions were tested for engine performance and emissions; results show that torque and power increases, BSFC also increases with the increase of concentrations of methanol in the blend (lliev et al. 2020).

Gasoline direct injection and Port FI engines were tested at various engine torques: 25,50 and $75 \%$; the soot particle emissions from a three way catalytic converter was also evaluated. Six different particles are observed to be ejected by the engine such as Organic, Iron Rich, Sulphur Rich, Calcium and manganese Rich (Xing et al. 2017).

Ethanol gasoline blends at proportions of 10, 20 and 100\% were tested on both laboratories with chassis dynamometer and on on-road conditions, observed that $2 \%$ reduction in the power output and torque; also in $\mathrm{CO}$ and NOx emissions with E2O blend fuel. $\mathrm{HC}$ and $\mathrm{CO}_{2}$ emissions wee slightly increased with E20 blend (Tibaquirá et al. 2018).

The timings of fuel injection and ignition; also the combustion chamber modifications were play important roles towards fuel consumption, proper mixing, superior combustion and emissions control; especially NOx and soot particle emissions (Shivakumar et al. 2020; Kumar 2020). NOx emissions were reduced to more than $90 \%$ using $\mathrm{HCCl}$ combustion technology with natural gas (Verma et al. 2021). 
The main objective of this work is to obtain the optimal results towards mainly the reduction of NOx and PM emissions; reduction in SFC and also other performance and emission characteristics, the combustion chamber geometry was modified by keeping the spark plug and the fuel injector at proper locations. The piston crown shape is modified like pent roof structure with a small bowl on one side of the pent roof (fuel injection side) to provide better turbulence, swirl and squish effects for better mixing of air with fuel. The injected fuel over a small bowl on the pent roof is directed towards the spark plug tip to initiate the combustion process. The fuel injection pressure was optimized at 150 bar using NI fuel injection driver. The ignition timing was optimized at $10^{\circ}$ bTDC using a self developed ignition driver circuit and the fuel injection timings were optimized using $\mathrm{NI}$ fuel injection driver. The compression ratio of an engine was maintained at 10:1 while modifying a piston crown shape. The exhaust gas recirculation was optimized at $10 \%$. Finally, the combined air-wall guided combustion chamber geometry GDI engine was tested towards its performance and emission characteristics.

\section{Materials And Methods}

\subsection{Combined Air-Wall Guided Combustion Chamber Geometry}

Figure 1 shows the modified piston shape with positions of spark plug and fuel injector for a combined air-wall guided combustion chamber geometry. The modified piston crown shape has a pent roof structure with a small bowl on one side of the pent roof surface (fuel injections side) to divert the injected fuel towards the spark plug tip in order to initiate the combustion of fuel with air.

Figure 2 shows the modified cylinder head with the provisions for fixing the spark plug, fuel injector and the pressure transducer. Separate sleeves were machined and welded through cylinder head using TIG welding, as per the positions mentioned over the piston crown in Figure 1.

\section{.2 Properties of Oxygenated Fuels Used}

The alternate fuels used in the experimental study are Ethanol, Methanol and N-Butanol. The proportions of 20,35 and $50 \%$ by volume alcohol-gasoline blends were prepared. Table 1 shows the physio-chemical properties of the mentioned blend fuels as well as gasoline. The octane number and density properties of each oxygenated fuel were higher than gasoline. However, the LHV of each oxygenated fuel was lower than gasoline.

Table 1 Physio-chemical properties of oxygenated fuels and gasoline 


\begin{tabular}{lllll} 
Properties & Gasoline & Methanol & N-Butanol & Ethanol \\
\hline Calorific Value $(\mathrm{kJ} / \mathrm{kg})$ & 45800 & 11778 & 33100 & 26700 \\
\hline
\end{tabular}
0.755
0.794
0.81
0.794

Boiling Point $\left({ }^{\circ} \mathrm{C}\right)$

$\begin{array}{llll}30-210 & 65 & 117 & 78.5\end{array}$

Flash Point $\left({ }^{\circ} \mathrm{C}\right)$

$\begin{array}{lllll}-40 & 12 & 34 & 13\end{array}$

Octane Number

87-94 111

96

$105-110$

Viscosity (cP)

$0.5-0.7$

Stoichiometric

Ratio

14:7:1

6.47

11.13

9:0:1

Auto Ignition Temperature $\left({ }^{\circ} \mathrm{C}\right)$

$\begin{array}{llll}247-280 & 465 & 345 & 365\end{array}$

\subsubsection{Methanol Properties}

Methanol is a colourless, alcoholic odour, flammable and volatile liquid, miscible with organic solvents and water. It has significantly higher octane number than gasoline. Low vapour pressure at higher concentrations will affect cold start performance of an engine and also evaporative emissions. High CR is required to operate an engine with methanol due to higher latent heat of vaporization which cools down the intake and allows more amount of fuel into the cylinder for combustion. Less soot emissions in the exhaust with methanol because of higher oxygen content and no carbon to carbon bonding. Due to lower heating value of methanol, requires modification of fuel supply system. Methanol blends with gasoline results in tendency of vaporization in fuel line, corrosive, chemical degradation and wear of fuel supply system components. Hence, lubricate additives are required.

\subsubsection{Ethanol Properties}

Ethanol is an aromatic, olefin and sulphur free compound. It has oxygen content of about $35 \%$, and $10 \%$ of ethanol equivalent to $3.7 \mathrm{wt} \%$ oxygen in gasoline. With high octane number of ethanol, higher thermal efficiency can be achieved with controlled engine knock. Ethanol blend increases it vapour pressure with blending ratios from 5 to $10 \%$ and then gradually decreases. With ethanol blend, more energy is needed to evaporate the fuel due to higher heat of vaporization which results in lower in-cylinder temperature. Also 
the cooled intake air increases it density and allows more fuel to be injecting, results in increased thermal efficiency. NOx emissions were reduced due to lower in-cylinder temperature. Lower heating value of ethanol than gasoline fuel leads to increased volumetric fuel consumption with ethanol blend. Ethanol has slightly higher density than gasoline which improves the volumetric fuel economy to some extent. Acetic acid as weak acidity content present in the ethanol which may affect long term durability, and strong acidity content may produce rapid corrosion.

\subsubsection{N-Butanol Properties}

N-Butanol has minimum miscibility with water but easily soluble with ethers, alcohol, glycols and hydrocarbons. It is highly flammable with flash point of around $35^{\circ} \mathrm{C}$. It can be naturally produced by fermentation of sugars and carbohydrates. It has lower vapour pressure with gasoline blend results in cold start problems with higher blend proportions, and has higher heating value than gasoline fuel.

\subsection{Methodology}

The various gasoline fuel blends of Methanol M20, M35 and M50; fuel blends of Ethanol E20, E35 and E50; fuel blends of N-Butanol B20, B35 and B50 are prepared before the start of experiments. The performance characteristics of the engine and the emissions from the exhaust has to be evaluated in order to find the merits and drawbacks of all the fuel blends when compared with gasoline at the same running conditions. The tests were conducted at constant $1500 \mathrm{rpm}$ speed, compression ratio of 10:1, 10\% EGR, 150 bar FIP with three split injections at different durations. The fuel supply system was controlled with the help of National Instruments fuel injection driver. The ignition timing was controlled with Arduino Uno controller with L298N motor drivers.

\section{Experimental Setup}

The test was conducted on a modified GDI engine where the 5hp, 4S, single cylinder diesel engine at CR of $16.5: 1$ and the engine displacement volume of 552.3cc was modified into a gasoline DI engine at compression ratio of 10:1. The tests were carried out on a test bed with eddy current dynamometer, and the block diagram of the GDI engine test bench is as shown in Figure 3. Fuel rail pressure and injection system was controlled by the National Instruments fuel injection driver and Ignition timing was controlled by self developed Arduino Uno controller with L298N motor drivers.

During tests, the concentrations of each emission were continuously recorded with the help of AVL gas analyzer and the fuel consumption was measured with the use of weighing balance. All the blends are tested under constant speed of $1500 \mathrm{rpm}, 10 \% \mathrm{EGR}, 150$ bar FIP and split injections at $320^{\circ}, 220^{\circ}$ and $100^{\circ}$ before TDC with injection durations of $4.5 \mathrm{~ms}, 9 \mathrm{~ms}$ and $3 \mathrm{~ms}$ respectively. The engine loading was done through eddy current dynamometer with controller. The proportions of 20,35 and $50 \%$ of gasohol blends were tested at different loading under steady state. The various parameters are evaluated such as: indicated mean effective pressure, specific fuel consumption, carbon monoxide, un-burnt hydrocarbons, oxides of nitrogen and Soot emission. 


\subsection{Uncertainty Analysis}

The evaluated uncertainty of variables such as $\mathrm{HC}, \mathrm{CO}, \mathrm{NOx}$, Soot, and in-cylinder pressure using AVL's 444 digas analyzer, $437 \mathrm{C}$ smoke meter, and Kistler piezoelectric pressure transducer instruments as shown in table 2. The error in the output results is due to environmental variations, calibration, observations, etc. Using a differential method, an error examination was made to endorse the accuracy of the experimental results. Error ' $r$ ' as a dependent variable of $C_{1}, C_{2}, C_{3} \ldots . . . C n$ and it can be represented by,

$$
\mathrm{R}\left[f\left(C_{1}, C_{2}, C_{3}, \ldots . . C_{n}\right)\right]=\sqrt{\sum\left[\left(\mathrm{C}_{\mathrm{i}} \times \mathrm{R}\left(\mathrm{C}_{\mathrm{i}}\right)^{2}\right)\right]}
$$

Utilizing the uncertainties of devices indicated in table 2, computed the uncertainty values of emission characteristics. The error depends on parameters $\mathrm{C}_{1}, \mathrm{C}_{2}, \mathrm{C}_{3}, \ldots \ldots \ldots . . . \mathrm{C}_{\mathrm{n}}$ can be estimated by,

$$
\frac{\Delta R}{R}=\left[\left(\frac{\Delta C_{1}}{C_{1}}\right)^{2}+\left(\frac{\Delta C_{2}}{C_{2}}\right)^{2}+\left(\frac{\Delta C_{3}}{C_{3}}\right)^{2}+. .+\left(\frac{\Delta C_{n}}{C_{n}}\right)^{2}\right]^{2}
$$

Expressed each variable error by $\Delta \mathrm{c}_{1} / \mathrm{c}_{1}$, where $\Delta \mathrm{C}_{1}$ is the precise value of the measuring instrument, $\mathrm{C}_{1}$ is the minimal rate. Utilizing the uncertainty of individual devices, determined the overall-uncertainty and it may be evaluated by,

$$
\begin{aligned}
& \mathrm{U}_{\text {overall }}=\sqrt{\left[\left(U_{C O}\right)^{2}+\left(U_{C O}\right)^{2}+\left(U_{C O}\right)^{2}+\left(U_{C O}\right)^{2}+\left(U_{C O}\right)^{2}\right]} \\
& \mathrm{U}_{\text {overall }}=\sqrt{\left[(0.2)^{2}+(0.2)^{2}+(0.2)^{2}+(1)^{2}+(1.2)^{2}\right]}= \pm 1.72
\end{aligned}
$$

\begin{tabular}{|c|c|c|c|}
\hline $\begin{array}{l}\text { Measuring } \\
\text { Variable }\end{array}$ & Range & Accuracy/Precision & Uncertainty \\
\hline $\mathrm{HC}$ & $\begin{array}{l}0-20,000 \text { ppm by } \\
\text { vol. }\end{array}$ & $\begin{array}{l}\varangle 200 \mathrm{ppm} \text { volume: } \pm 10 \mathrm{ppm} \text { volume } \geq 200 \mathrm{ppm} \\
\text { vol. : } \pm 5 \%\end{array}$ & $\pm 0.2 \%$ \\
\hline $\mathrm{CO}$ & $0-10 \%$ by vol. & $₫ 0.6 \%$ vol. : $\pm 0.03 \%$ vol. & $\pm 0.2 \%$ \\
\hline NOx & $\begin{array}{l}0-5,000 \mathrm{ppm} \text { by } \\
\text { vol. }\end{array}$ & $\begin{array}{l}\otimes 500 \text { ppm vol. : } \pm 50 \text { ppm vol. } \geq 500 \text { ppm vol. : } \\
\pm 10\end{array}$ & $\pm 0.2 \%$ \\
\hline Smoke & 0-100\% opacity & $\pm 0.2 \%$ & $\pm 1.0 \%$ \\
\hline $\begin{array}{l}\text { In-cylinder } \\
\text { pressure }\end{array}$ & 1-100 bar & \pm 0.1 bar & $\pm 1.2 \%$ \\
\hline
\end{tabular}

Table 2 Range, precision and uncertainty of measuring devices.

\section{Results And Discussion}

The Air-Wall guided mode modified GDI engine was tested with the mentioned proportions of gasohol fuels at $1500 \mathrm{rpm}, 10 \%$ EGR and fuel injection pressure of 150 bars with three split injections at different 
durations. The fuel consumption was calculated using weighing balance and manual calculations. From the calculated values of SFC and IMEP; also from the measured emission values of CO, HC, NOx and Soot; the graphs were drawn for all these parameter with respect to engine torque at no load, $25 \%$ load, $50 \%$ load, $75 \%$ load and $100 \%$ load.

\subsection{Performance Analysis}

The combined air-wall guided mode modified GDI engine was tested for SFC and IMEP with the mentioned gasohol blended fuels at the specified fixed conditions. The engine fuel consumption was measured using weighing balance; SFC and IMEP were calculated at various loads/torque values.

\subsubsection{Specific Fuel Consumption Analysis}

SFC gradually increases with the increase of engine torque from low load to high load. From Figure 4, it is observed that the SFC of gasoline and various blends were increasing with increase in engine torque; at $20 \%$ proportion, SFC of N-Butanol blends were comparatively lower than gasoline and other fuel blends because of higher calorific values; the SFC of Methanol fuel blends were comparatively higher than gasoline and other blend fuels because of very low calorific value and higher \% weight of oxygen. At $20 \%$ blend, SFC of Ethanol is lower than gasoline and other fuel blends because of rich in latent heat of vaporization.

\subsubsection{Indicated Mean Effective Pressure Analysis}

IMEP value of gasoline and other fuel blends increases with the increase of torque from low load to high load. Figure 5 shows the variations of IMEP at various torque values and it is observed that the IMEP values of gasoline and other fuel blends were increasing with the increase of torque. The IMEP of Ethanol fuel blends were comparatively higher than gasoline and other fuel blends because of higher latent heat of vaporization property, better mixing of air with fuel blend and superior combustion; and maximum at E20 fuel blend. IMEP of Methanol and N-Butanol fuel blends were higher at $20 \%$ proportion than $35 \%$ and $50 \%$ proportions.

\subsection{Emissions Analysis}

The combined Air-Wall guided mode modified GDI engine was tested for CO, UBHC, NOx and Soot emissions with the mentioned gasoline blended fuels at the specified fixed conditions. The emission concentrations of $\mathrm{CO}, \mathrm{UBHC}$, NOx and Soot were measured at various loads/torque values using AVL's 444 Digas analyzer and $437 \mathrm{C}$ smoke meter.

\subsubsection{Carbon Monoxide Emission Analysis}

Figure 6 shows the variation of $\mathrm{CO}$ from gasoline fuel and other fuel blends at various torque values. It is observed that the $\mathrm{CO}$ emissions were increased for gasoline, Methanol and Ethanol fuel blend ratios 
because of comparatively higher latent heat of evaporation and better mixing (Ribeiro et al. 2018); and decreased for N-Butanol fuel blends. With the increase of engine torque/load, the $\mathrm{CO}$ emission concentrations were decreased because of increase in turbulence effect leads to proper mixing of air with fuel. N-Butanol shows lower $\mathrm{CO}$ emission concentration at $35 \%$ of fuel blend because of higher calorific value when compared to Ethanol and Methanol fuels.

\subsubsection{Un-burnt Hydrocarbon Emission Analysis}

Figure 7 shows the variation of UBHC from gasoline fuel and other fuel blends at various torque values. It is observed that the UBHC emissions were increased for gasoline and Methanol fuel blend ratios because of comparatively lower density fuel property; and decreased for N-Butanol fuel blends because of high density and viscosity properties. With the increase of engine torque/load, the UBHC emission concentrations were decreased increase in turbulence effect leads to proper mixing of air with fuel. M50 shows lower UBHC than M20 and M35 blend ratios due to more \% weight of oxygen. E20 fuel blend shows lower UBHC emission than higher Ethanol blend ratios, it because of comparatively higher viscosity and density of Ethanol fuel (Ribeiro et al. 2018).

\subsubsection{Oxides of Nitrogen Emission Analysis}

Figure 8 shows the variation of NOx emission from gasoline and other fuel blends at various engine torque values and it shows that the NOx emission concentrations were boosted up with the increase of torque due to proper mixing and improved combustion rate, because of better turbulence effect towards higher loads. NOx emission concentration increases whereas other fuel blends, NOx emission concentration minimized with the boost up of blend ratio (Duarte et al. 2021). NOx emissions concentration is lower at M50 than M20 and M35 fuel blends; its concentration for decreases with the increase of fuel blend proportions and higher for N-Butanol blends than other fuel blends because of higher calorific value.

\subsubsection{Soot Particle Emission Analysis}

Figure 9 shows the variation of Soot emission from gasoline fuel and other fuel blends at various torque values. It is observed that the Soot emissions were increased with the increase of engine torque, because of increase in fuel consumption. From the graph, it is clear that the Soot emission concentrations were comparatively decreased with the increase of all blend ratios may be due to improved turbulence effect with the increase of engine load leads to better mixing of air with fuel blends and results in superior combustion of mixture (Coufalík et al. 2019; Duarte et al. 2021). Also, the Soot emissions concentration were higher for N-Butanol fuel blends than Methanol and Ethanol fuel blends, because of higher density and viscosity properties.

\section{Conclusion}


In this experiment, the effects of methanol-gasoline, ethanol-gasoline, N-Butanol-gasoline on the fuel consumption, exhaust emissions, and running performance of a combined air-wall guided mode GDI engine were analyzed. The tests were carried out at steady state with the blend ratios of 20,35 and $50 \%$ by volume. The obtained results were compared with the characteristics of gasoline. The variations are summarized and listed below:

- Using Methanol-gasoline blends at different ratios, it is observed that the concentration of $\mathrm{CO}$ and $\mathrm{HC}$ decreases $2.8 \%$ and $3.8 \%$, when large proportion of methanol was blended. And the $\mathrm{NO}_{\mathrm{X}}$ concentration decreased $7.15 \%$ with increase in methanol proportion in the fuel. The concentration of $\mathrm{NO}_{X}$ is found least in measure when $50 \%$ methanol is used. As the methanol concentration increases the Specific Fuel Consumption also increased as it is observed that the SFC has rise from M20 to M50 with an increment of 3.32\%. The Indicative mean effective pressure [IMEP] is seen decreased by $4.87 \%$, with increase in the methanol proportion. The Soot concentration in the exhaust emission was found higher when low proportion of methanol used and found lower when higher methanol proportion used with a decrement of $6.67 \%$.

- The concentration of the un-burnt hydrocarbons in the exhaust gases are lowest when using $20 \%$ ethanol and highest when using $50 \%$ ethanol showing an increment of $3.67 \%$. The CO concentration is found decreasing $2.7 \%$, with increase in ethanol percentage. The Soot concentration in the exhaust gas is found decreased $14.3 \%$, as the proportion of ethanol increased. The IMEP is found increased $6.12 \%$, with increase in the ethanol used in the blend. $\mathrm{NO}_{\mathrm{X}}$ emissions are decreased $7.15 \%$, as ethanol percentage increases. SFC decreased by $3.82 \%$ at $20 \%$ ethanol blend.

- The $\mathrm{CO}$ emission decreased $0.256 \%$, with increase in $\mathrm{N}$-Butanol. The $\mathrm{NO}_{\mathrm{X}}$ emissions are found highest at low N-Butanol proportion and lowest when using high N-Butanol concentration with a decrement of $6.67 \%$. Soot emission is also decreased $4.44 \%$ as N-Butanol increased. Un-burnt hydrocarbons also decreased $0.93 \%$, with increase in N-Butanol. SFC increased $2.30 \%$, with increase in ratio of N-Butanol. IMEP decreased $1.84 \%$, with increasing N-Butanol.

From the discussion over the results obtained, the ethanol $20 \%$ blend with gasoline shows major beneficial environmental impact towards emissions reduction than other alcoholic fuels when tested with the combined air-wall guided combustion chamber geometry GDI engine at the specified operating conditions.

\section{Abbreviations}

GDI Gasoline Direct Injection

SFC Specific Fuel Consumption

bTDC before Top Dead Centre

COP Coil on Plug 


\begin{tabular}{ll} 
PM & Particulate Matter \\
CO & Carbon Monoxide \\
UBHC & Unburned Hydrocarbon \\
THC & Total Hydrocarbon \\
DI - & Direct Injection \\
IC & Internal Combustion \\
NI & National Instruments \\
IMEP & Indicated Mean Effective Pressure \\
DAQ & Data Acquisition \\
NOx & Oxides of Nitrogen \\
FIP & Fuel Injection Pressure \\
WOT & Wide Open Throttle \\
GPF & Gasoline Particulate Filter \\
CC & Combustion Chamber \\
CFD & Computational Fluid Dynamics \\
HRR & Heat Release Rate \\
TR & Tumble Ratio \\
\hline
\end{tabular}

$\mathrm{HCCl} \quad$ Homogeneous Charge Compression Ignition

\section{Declarations}

\section{Authors Contributions}

Shivakumar N: Conceptualization, Methodology, Investigation, Resources, Data curation, Writing - original draft, Writing - original draft, review \& editing, Visualization. Dr. Kumaresan G: Investigation, Resources, Data curation, Writing - review \& editing, Supervision, Project administration,

\section{Funding}


The authors declare that no funds, grants, or other support were received during the preparation of this manuscript.

\section{Competing Interests}

The authors have no relevant financial or non-financial interests to disclose.

\section{Availability of data and materials}

The datasets used and/or analyzed during the current study are available from the corresponding author on reasonable request.

\section{Ethics approval}

The authors declare that the submitted manuscript is original. They acknowledge the current review has been conducted ethically, and the final shape of the research has been agreed upon by all authors.

\section{Consent to participate}

The authors consent to participate in this research study.

\section{Consent for publish}

All the author's consent to publish the current research in the ESPR journal.

\section{References}

- Abdulazeez, Abdulrahman \& Adisa, Ademola \& Dandakouta, Habou. Performance and Emissions Analysis of N-Butanol Blended with Gasoline in Spark Ignition Engine. International Journal of Engineering and Management Research. 2018, 8. 10.31033/ijemr.8.4.19.

- Ahmad, Tabrez. Fuel Blending in India: Learnings and Way Forward (2018).

- C. Saggese, C. M. Thomas, S. W. Wagnon, G. Kukkadapu, S. Cheng, D. Kang, S.S. Goldsborough, W.J. Pitz, An improved detailed chemical kinetic model for C3-C4 linear and iso-alcohols and their blends with gasoline at engine-relevant conditions, Proc. Combust. Inst. 38, 1, 2021, 415-423, ISSN 1540 7489, https://doi.org/10.1016/j.proci.2020.07.023.

- Chandra Mishra P, Ishaq RB, Khoshnaw F. Mitigation Strategy of Carbon Dioxide Emissions through Multiple Muffler design exchange and Gasoline-Methanol blend replacement. Journal of Cleaner Production. Volume 286, 1 March 2021, 125460. https://doi.org/10.1016/j.jclepro.2020.125460.

- Coufalík, P., Matoušek, T., Křumal, K. et al. Content of metals in emissions from gasoline, diesel, and alternative mixed biofuels. Environ Sci Pollut Res 26, 29012-29019 (2019). https://doi.org/10.1007/s11356-019-06144-4.

- Duarte, G.T., de Alencar Nääs, I. \& da Silva Lima, N.D. Estimating the urban environmental impact of gasoline-ethanol blended fuels in a passenger vehicle engine. Environ Sci Pollut Res 28, 63977- 
63988 (2021). https://doi.org/10.1007/s11356-021-13432-5.

- Fennell, D. , Herreros, J. M. and Tsolakis, A. (2014) Improving gasoline direct injection (GDI) engine efficiency and emissions with hydrogen from exhaust gas fuel reforming. International Journal of Hydrogen Energy, volume 39 (10): 5153-5162 https://doi.org/10.1016/j.ijhydene.2014.01.065.

- Goldsborough, S. Scott, Cheng, Song, Kang, Dongil, Saggese, Chiara, Wagnon, Scott W., \& Pitz, William J. Effects of isoalcohol blending with gasoline on autoignition behavior in a rapid compression machine: Isopropanol and isobutanol. United States.

https://doi.org/10.1016/j.proci.2020.08.027.

- Gorbatenko, I, Tomlin, AS, Lawes, M, (2019). Experimental and Modelling Study of the Impacts of nButanol Blending on the Auto-Ignition Behaviour of Gasoline and its Surrogate at Low Temperatures. Proceedings of the Combustion Institute, 37 (1). pp. 501-509. ISSN 1540-7489. https://doi.org/10.1016/j.proci.2018.05.089.

- Haifeng Liu, Xichang Wang, Diping Zhang, Fang Dong, Xinlu Liu, Yong Yang, Haozhong Huang, Yang Wang, Qianlong Wang, Zunqing Zheng. Investigation on Blending Effects of Gasoline Fuel with NButanol, DMF, and Ethanol on the Fuel Consumption and Harmful Emissions in a GDI Vehicle. Energies. 2019, 12, 1845. https://doi.org/10.3390/en12101845.

- Hoang, A.T., Nižetić, S. \& Pham, V.V. A state-of-the-art review on emission characteristics of SI and Cl engines fueled with 2,5-dimethylfuran biofuel. Environ Sci Pollut Res 28, 4918-4950 (2021). https://doi.org/10.1007/s11356-020-11629-8.

- Iliev, Simeon. (2020). Investigation of the Gasoline Engine Performance and Emissions Working on Methanol-Gasoline Blends Using Engine Simulation. 10.5772/intechopen.92858.

- Khan, T.M.Y. A Review of Performance-Enhancing Innovative Modifications in Biodiesel Engines. Energies. 2020, 13, 4395. https://doi.org/10.3390/en13174395.

- Kumar S. Piston Crown Profile Modifications for Various Combustion Mode Strategies of Modified GDI Engine towards NOx and PM Reduction. International Journal of Automotive Science And Technology. 2020, 4(4):289-294. https://doi.org/10.30939/ijastech..796526.

- L. S. Khuong, H. H. Masjuki, N.W.M. Zulkifli, E. Niza Mohamad, M. A. Kalam, Abdullah Alabdulkarem, A. Arslan, M. H. Mosarof, A. Z. Syahira, M. Jamshaida. Effect of gasoline bio-ethanol blends on the properties and lubrication characteristics of commercial engine oil. The Royal Society of Chemistry. 2017, 7, 15005-15019.

- Lanyi Zhang, Jane Lin, Rongzu Qiu. Characterizing the toxic gaseous emissions of gasoline and diesel vehicles based on a real-world on-road investigation. Journal of Cleaner Production. 286, 2021, 124957, ISSN 0959-6526, https://doi.org/10.1016/j.jclepro.2020.124957.

- Lapointe, S., Zhang, K., and McNenly, M. J.. Reduced chemical model for low and high-temperature oxidation of fuel blends relevant to internal combustion engines . United States: N. p., 2018. Web. https://doi.org/10.1016/j.proci.2018.06.139 .

- N Shivakumar, G A C Jayaseelan, Parthiban, Ahmed, Akshay. (2020). Ignition Timing and Fuel Injection Timing Control using Arduino and Control Drivers. IOP Conf. Ser.: Mater. Sci. Eng. 993, 
012019. https://doi.org/10.1088/1757-899X/993/1/012019.

- P. Iodice, G. Langella, A. Amoresano, Ethanol in Gasoline Fuel Blends: Effect on Fuel Consumption And Engine out Emissions of SI Engines in Cold Operating Conditions. Applied Thermal Engineering. (2017), https://doi.org/10.1016/j.applthermaleng.2017.11.090.

- Prakash Chandra Mishra, Sourav Kumar Kar, Harsit Mishra. Effect of perforation on exhaust performance of a turbo pipe type muffler using methanol and gasoline blended fuel: A step to NOx control. Journal of Cleaner Production. 2018. https://doi.org/10.1016/j.jclepro.2018.02.236.

- Puli. Danaiah , P. Ravi Kumar \& D. Vinay Kumar. Effect of Methanol Gasoline Blended Fuels on the Performance and Emissions of SI Engine. December 2013International Journal of Ambient Energy 34(4). https://doi.org/10.1080/01430750.2012.755609.

- R. Sameeth Raj, S. Lesslins Raja Deva Doss N. Surendar, S. Gowthaman. Effect of Pre-Heated Air on Spark Ignition Engine Fuelled with Petrol-Ethanol Blends. International Journal of Recent Technology and Engineering (IJRTE). 2019, 8, 4S2, ISSN: 2277-3878.

- Ribeiro, C.B., Martins, K.G., Gueri, M.V.D. et al. Effect of anhydrous ethanol/gasoline blends on performance and exhaust emissions of spark-ignited non-road engines. Environ Sci Pollut Res 25, 24192-24200 (2018). https://doi.org/10.1007/s11356-018-2476-2.

- S.V. Karthic, M. Senthil Kumar, G. Nataraj, P. Pradeep. An assessment on injection pressure and timing to reduce emissions on diesel engine powered by renewable fuel. Journal of Cleaner Production. 255, 2020, 120186, ISSN 0959-6526, https://doi.org/10.1016/j.jclepro.2020.120186.

- Shukla M. K, Singh E, Singh N, Singal, S. K. Prospects of 2, 5-dimethylfuran as a fuel: physicochemical and engine performance characteristics evaluation. Journal of Material Cycles and Waste Management. 2014, 17, 3, 459-464. https://doi.org/10.1007/s10163-014-0305-3.

- Tibaquirá, J.E.; Huertas, J.I.; Ospina, S.; Quirama, L.F.; Niño, J.E. The Effect of Using Ethanol-Gasoline Blends on the Mechanical, Energy and Environmental Performance of In-Use Vehicles. Energies. 2018, 11, 221. https://doi.org/10.3390/en11010221.

- Verma, .K., Gaur, S., Akram, T. et al. Emissions from homogeneous charge compression ignition (HCCl) engine using different fuels: a review. Environ Sci Pollut Res (2021).

https://doi.org/10.1007/s11356-021-15602-x.

- Wei Yanju, Liu Shenghua, Li Hongsong, Yang Rui, Liu Jie, and Wang Ying. Effects of Methanol/Gasoline Blends on a Spark Ignition Engine Performance and Emissions. Energy \& Fuels. 2008, 22, 1254-1259.

- Xing J, Shao L, Zheng R, Peng J, Wang W, Guo Q, Wang Y, Qin Y, Shuai S, Hu M. Individual particles emitted from gasoline engines: Impact of engine types, engine loads and fuel components. Journal of Cleaner Production. 2017. https://doi.org/10.1016/j.jclepro.2017.02.056.

- Xu, H., \& Wang, C. (2016). A comprehensive review of 2,5-dimethylfuran as a biofuel candidate. In Biofuels from Lignocellulosic Biomass: Innovations beyond Bioethanol (pp. 105-129). (Biofuels from Lignocellulosic Biomass: Innovations beyond Bioethanol). WileyBlackwell. https://doi.org/10.1002/9783527685318.ch5. 
- Zheng X, Zhang S, Wu Y, Xu G, Hu J, He L, Wu X, Hao J. Measurement of particulate polycyclic aromatic hydrocarbon emissions from gasoline light-duty passenger vehicles. Journal of Cleaner Production. (2018), https://doi.org/10.1016/j.jclepro.2018.03.078.

- Zihe Gao, Huaxian Wan, Jie Ji, The effect of blend ratio on the combustion process of mutually stratified blended fuels pool fire, Proceedings of the Combustion Institute, volume 38, issue 3, 2021, pages 4995-5003. https://doi.org/10.1016/j.proci.2020.08.045.

\section{Figures}

\section{SPARK PLUG}

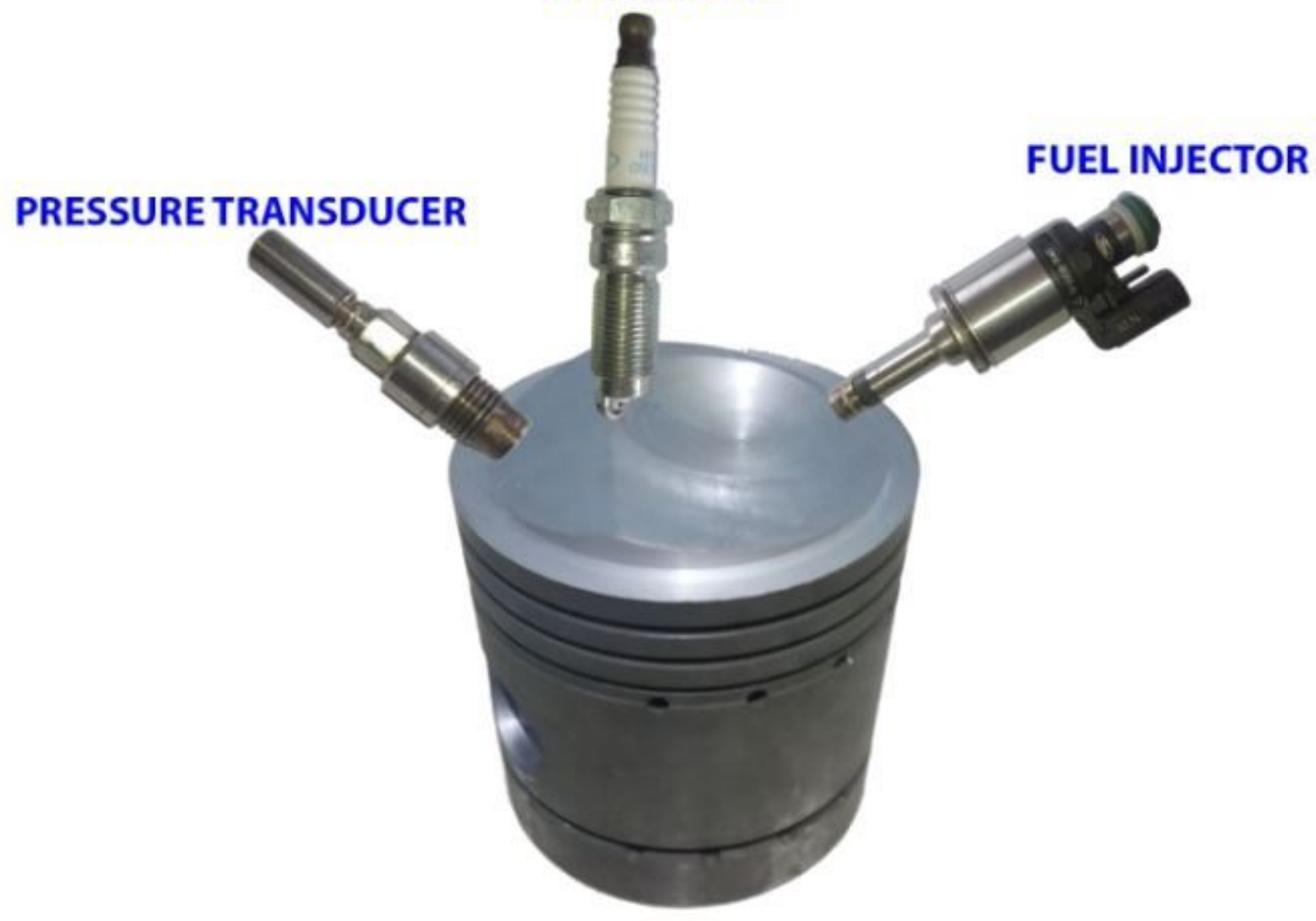

Figure 1

Piston Crown Modified Shape with Spark Plug and Fuel Injector Positions. 

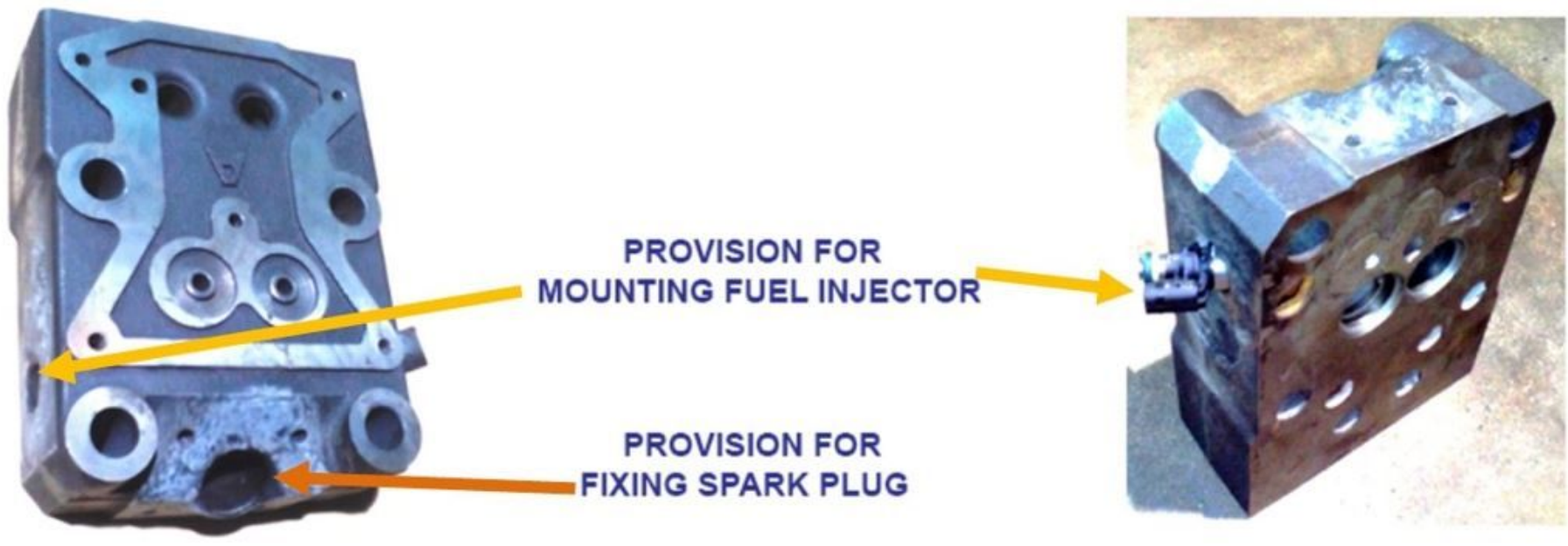

\section{Figure 2}

Modified Cylinder Head with Provisions for fixing Spark Plug and Fuel Injector.

1. CRNAK POSITION SENSUR

2. CAM PUSITION SENSUR

3. SPARK PLUG WITH IGNITION COIL

4. RAIL PRESSURE SENSDR

5. TRIGGER WHEEL

6. INLET MEETERING VALVE
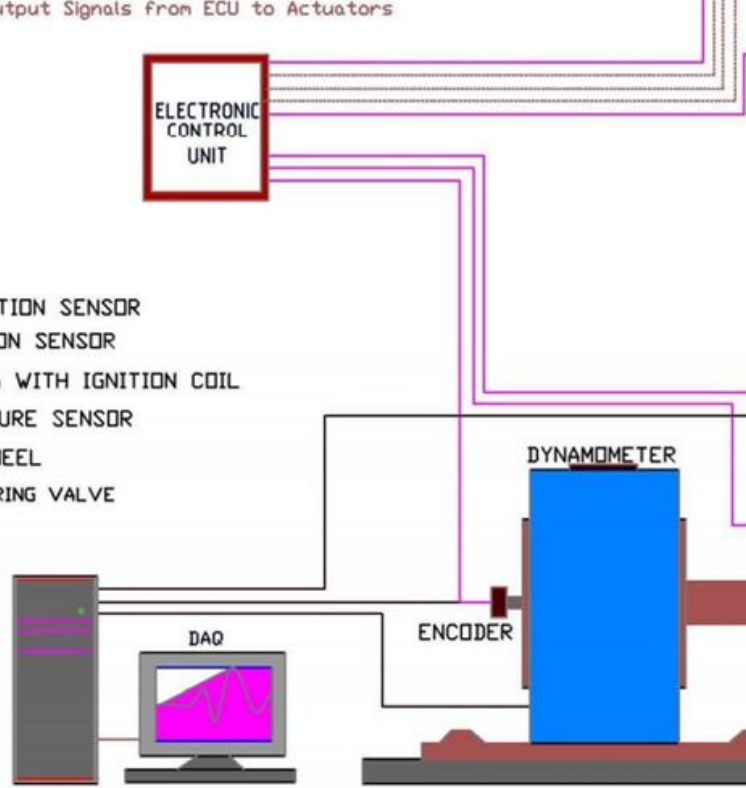


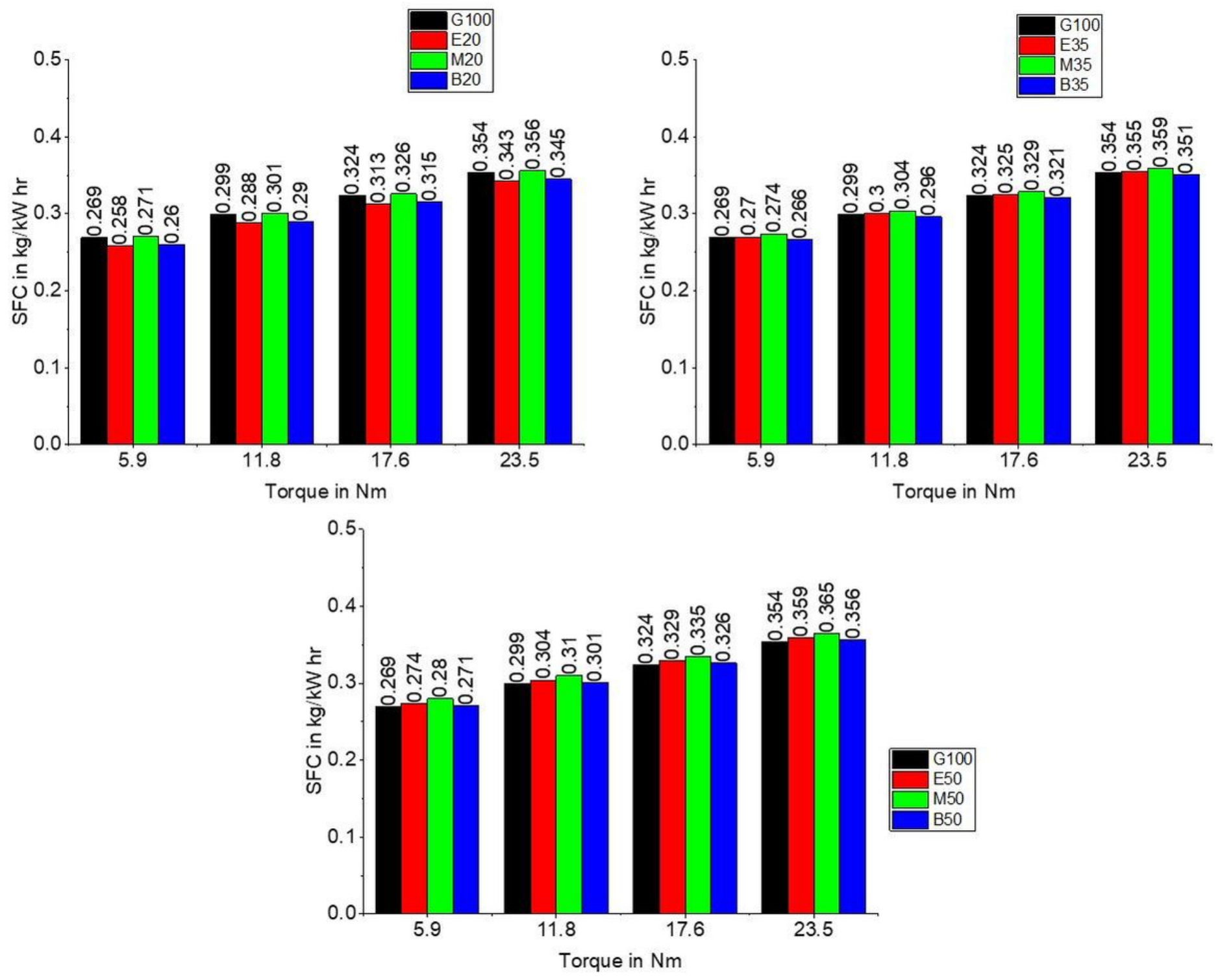

Figure 4

Variation of SFC at various Torque values for different blended fuels. 

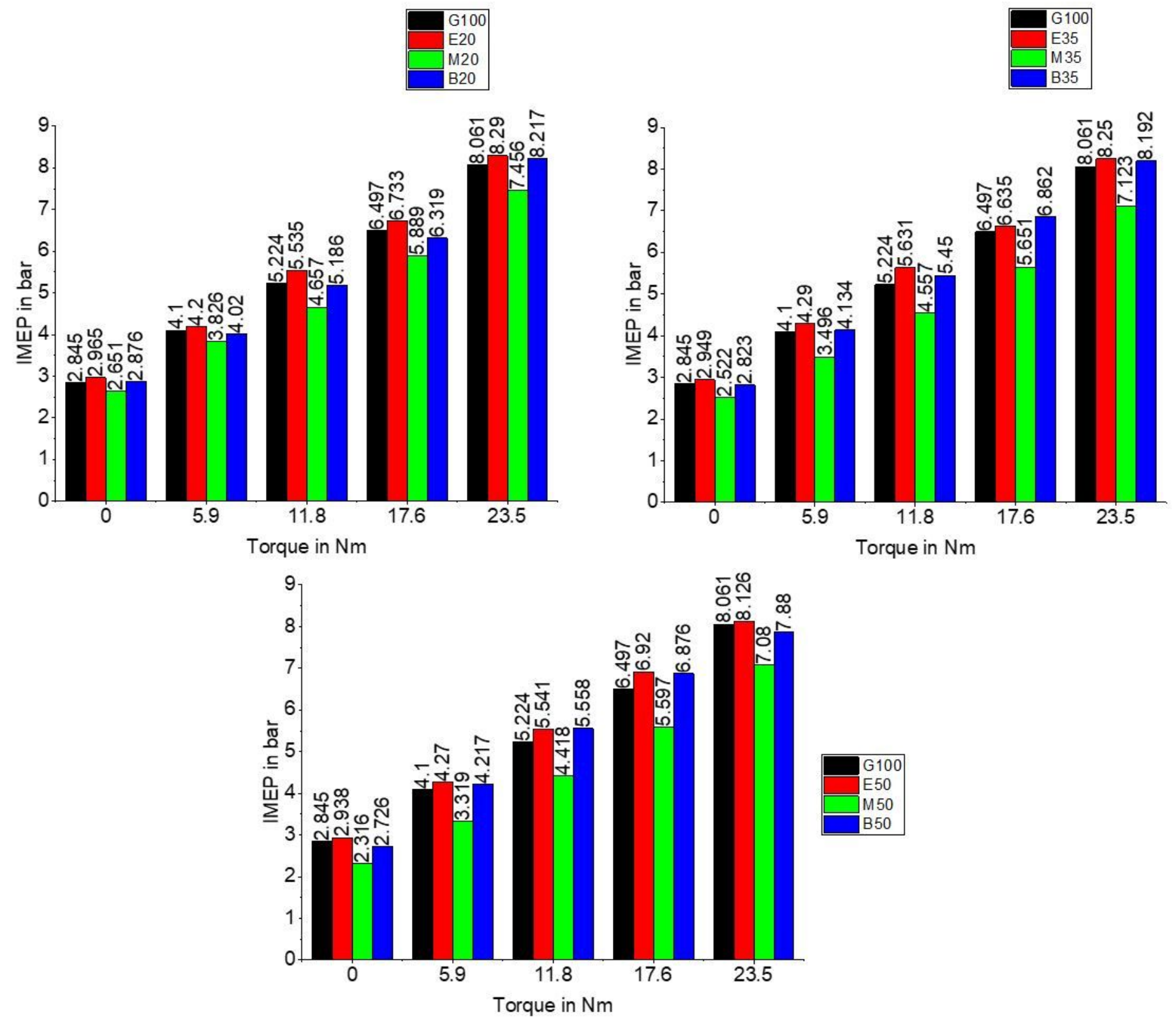

Figure 5

Variation of IMEP at various Torque values for different blended fuels. 

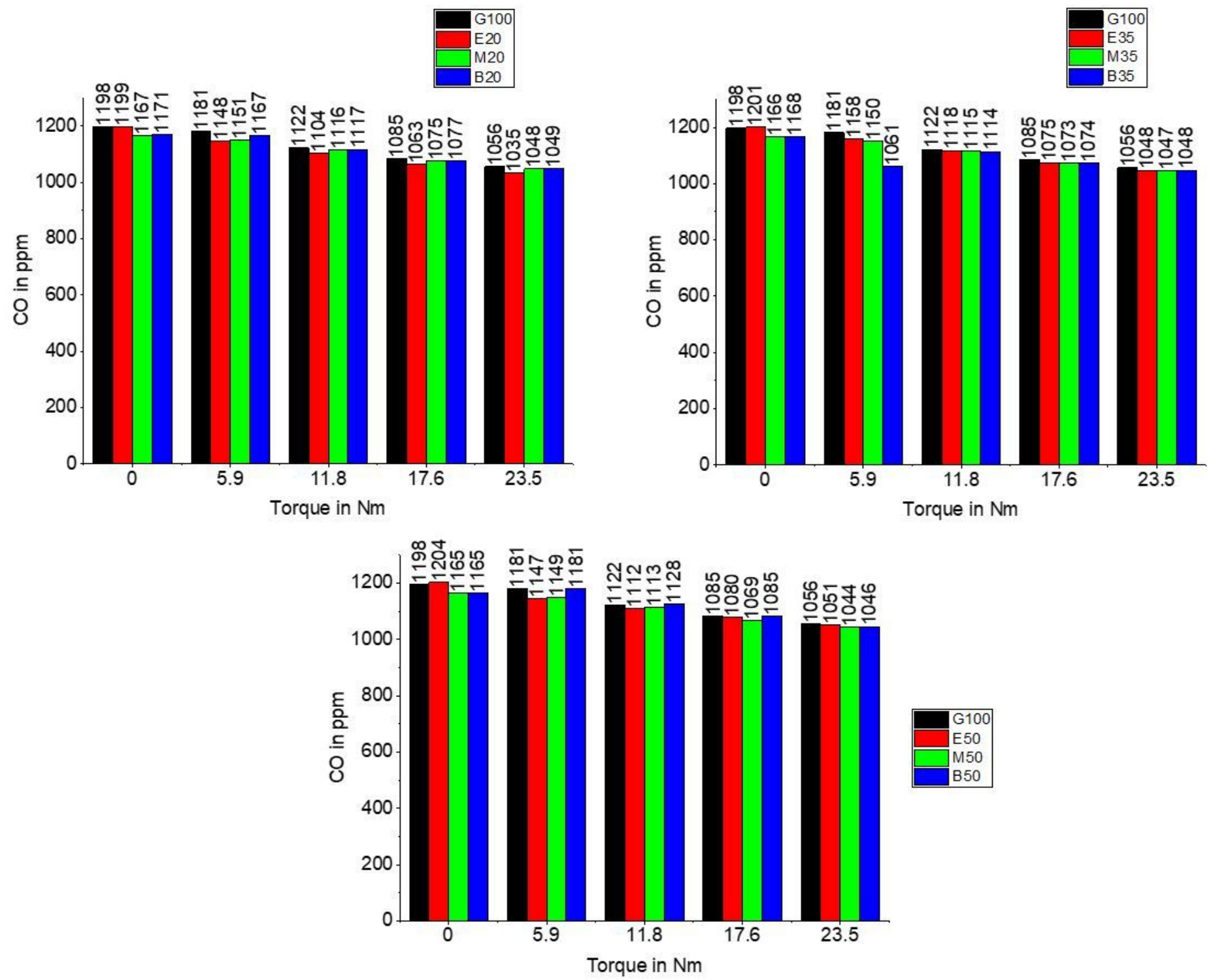

Figure 6

Variation of $\mathrm{CO}$ emission at various Torque values for different blended fuels 

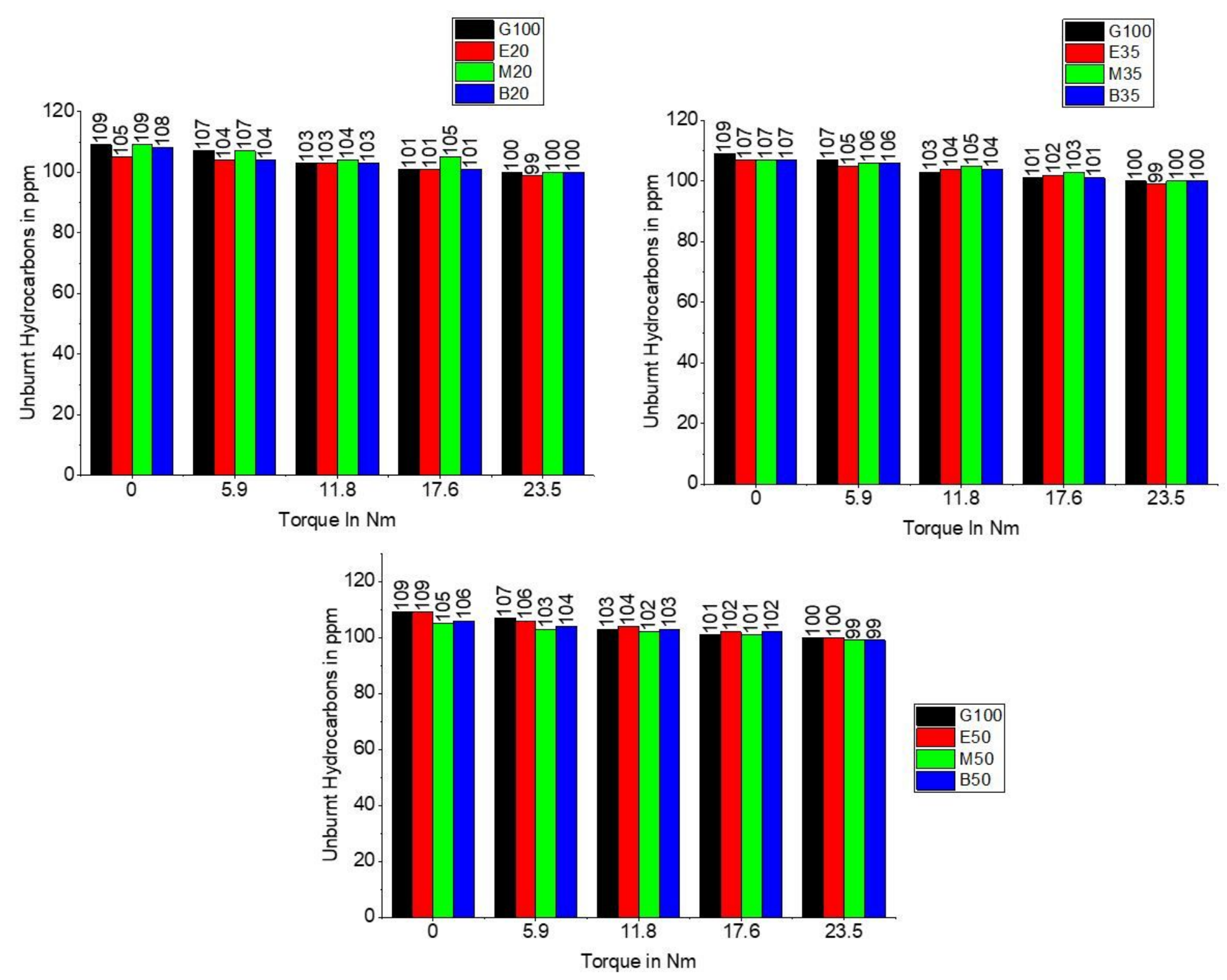

Figure 7

Variation of UBHC emission at various Torque values for different blended fuels 

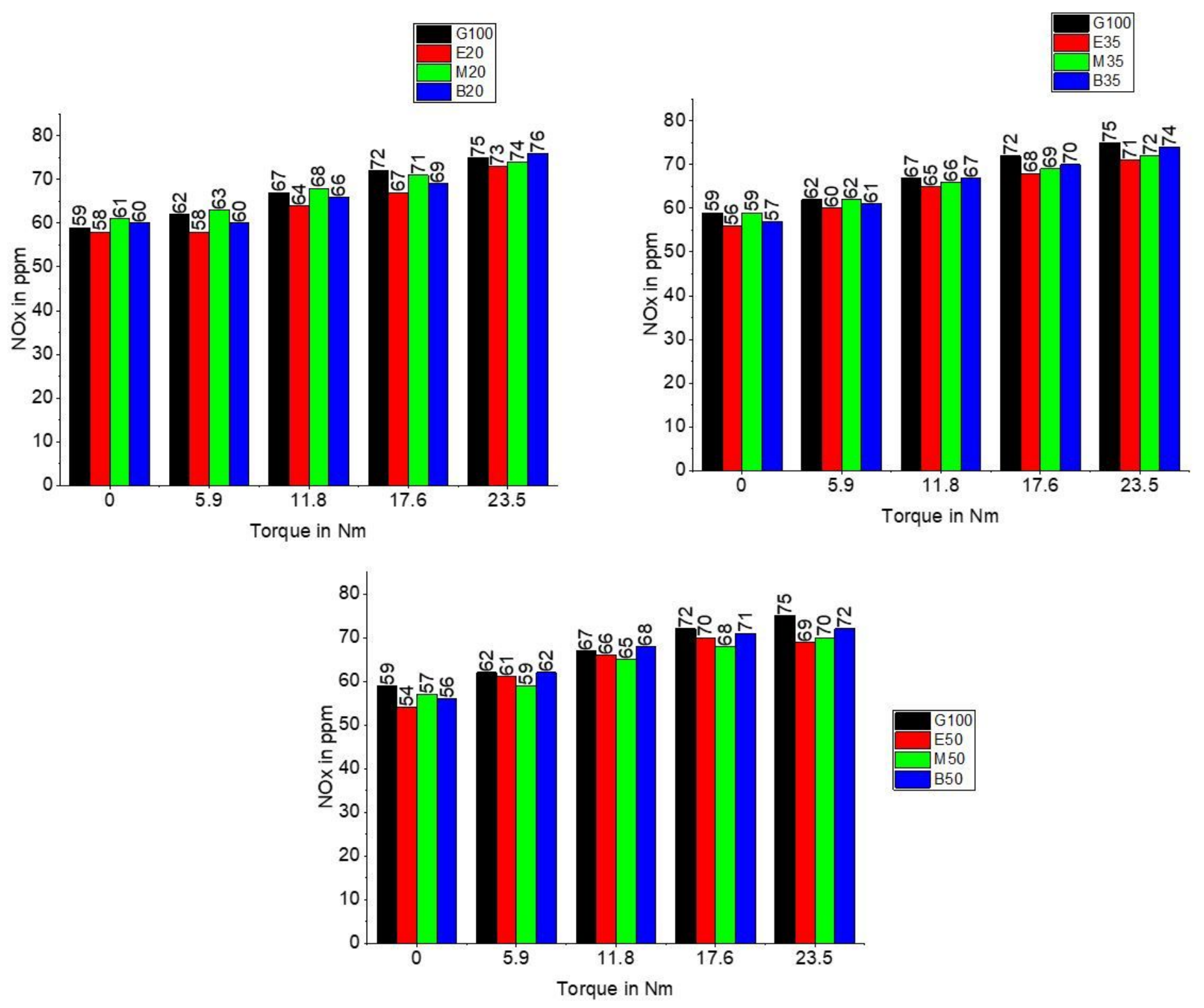

Figure 8

Variation of NOx emission at various Torque values for different blended fuels 

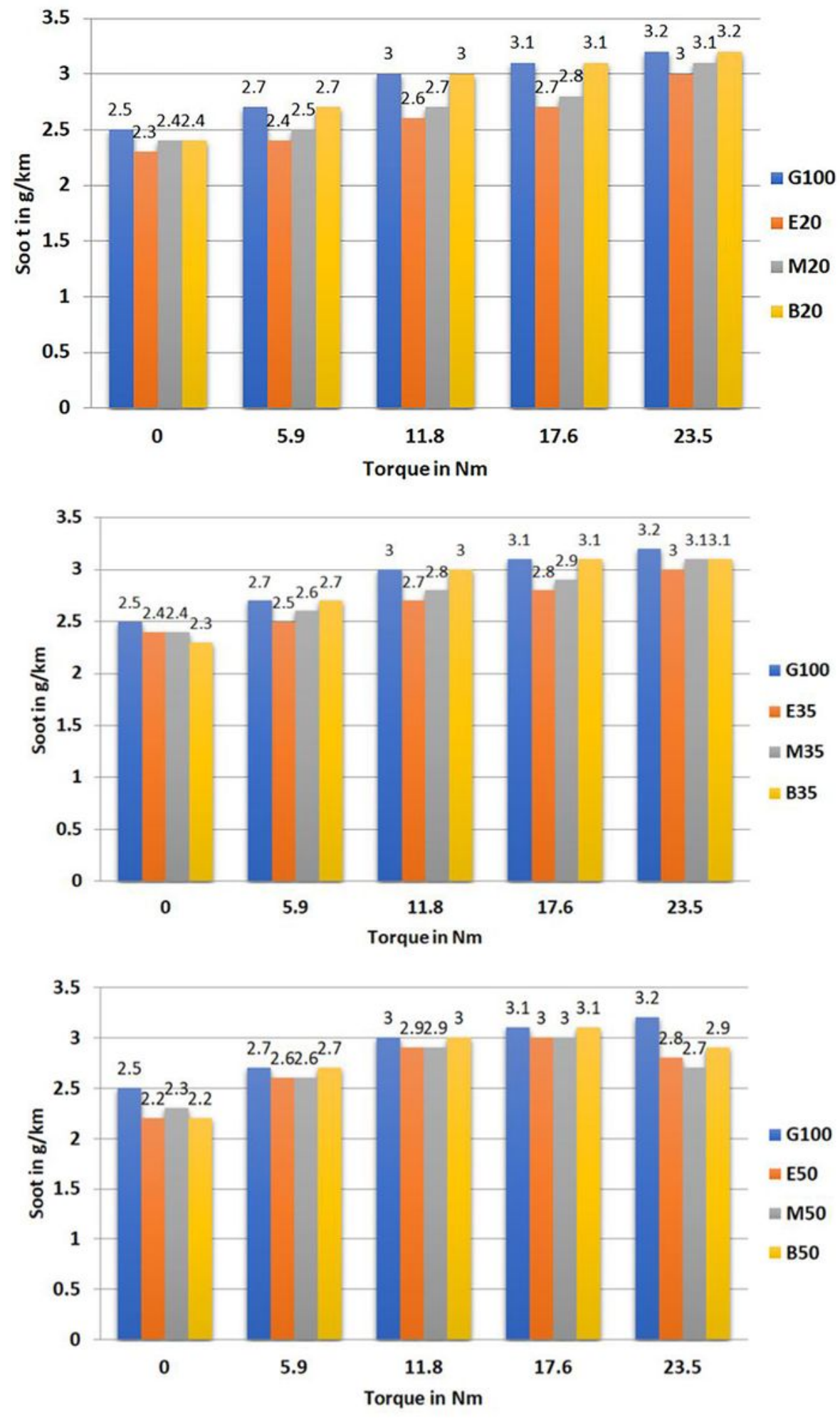

Figure 9

Variation of NOx emission at various Torque values for different blended fuels 